\title{
Nematode infection in the lizard Bogertia lutzae (Loveridge, 1941) from the Atlantic forest in north-eastern Brazil
}

\author{
R.W. Ávila ${ }^{1 *}$, L.A. Anjos ${ }^{2}$, U. Gonçalves ${ }^{3}$, E.M.X. Freire ${ }^{4}$, \\ W.O. Almeida ${ }^{5}$ and R.J. da Silva ${ }^{2}$ \\ ${ }^{1}$ Programa de Pós-Graduação em Biologia Geral e Aplicada, UNESP, \\ Distrito de Rubião Jr., s/nº, CEP 18618-000 Botucatu, SP, Brazil: \\ ${ }^{2}$ Departamento de Parasitologia, Instituto de Biociências, UNESP, Distrito \\ de Rubião Jr., s/nº CEP 18618-000 Botucatu, SP, Brazil: ${ }^{3}$ Museu de Historia \\ Natural, Universidade Federal de Alagoas, Av. Aristeu de Andrade, \\ $N^{\circ}$ 452, Farol, CEP 57021-090 Maceió, Alagoas, Brazil: ${ }^{4}$ Departamento de \\ Botânica, Ecologia e Zoologia, Centro de Biociências, Universidade Federal \\ do Rio Grande do Norte, Campus Universitário, CEP 59072-970 Natal-RN, \\ Brazil: ${ }^{5}$ Departamento de Química Biológica/CCBS, Universidade \\ Regional do Cariri, R. Cel Antônio Luiz, 1161, CEP 63105-000 Crato, \\ CE, Brazil
}

(Accepted 19 August 2009; First Published Online 18 September 2009)

\begin{abstract}
Endoparasites associated with the small bromelicolous lizard Bogertia lutzae, a poorly studied phyllodactylid inhabitant of north-eastern Brazil, were studied. Fifty-seven specimens collected from the Atlantic Forest of Alagoas state were dissected. Only one species of parasite, the nematode Spauligodon oxkutzcabiensis, was found, with a prevalence of $22.8 \%$. The intensity of infection was $2.62 \pm 1.19$, and neither the prevalence nor mean intensity differed between the sexes. There was no correlation between lizard body size and intensity of infection. An aggregated pattern of distribution $(D=0.813)$ of $S$. oxkutzcabiensis was found in this lizard host population. Bogertia lutzae represents a new host recorded for S. oxkutzcabiensis, a parasite reported for the first time for Brazil.
\end{abstract}

\section{Introduction}

Ecological studies of helminths associated with Brazilian lizards have recently increased (Rocha et al., 2003; Vrcibradic et al., 2007), although most available data deal with lizards inhabiting the coastal sand dunes in south-eastern Brazil (Van Sluys et al., 1997; Vrcibradic et al., 2000). Studies considering lizards from other biomes or Brazilian regions are even scarcer and restricted to descriptive and/or taxonomic surveys (Vicente et al., 2000; Durette-Desset et al., 2006).

The small phyllodactylid gecko Bogertia lutzae (Loveridge, 1941) is a bromelicolous species that occurs in

*E-mail: robsonavila@gmail.com coastal sand dunes and Atlantic Forest areas from Pernambuco state to Bahia state in north-eastern Brazil (Carvalho et al., 2005). Available information on the ecology of this species is scarce, and no records of endoparasites infecting $B$. lutzae have been published. In the present study, we survey the helminth fauna associated with a population of B. lutzae from an Atlantic forest site in north-eastern Brazil.

\section{Materials and methods}

Fieldwork was conducted in the Mata da Serra da Saudinha $\left(09^{\circ} 22^{\prime} \mathrm{S}, 35^{\circ} 45^{\prime} \mathrm{W}\right)$, a 1210 ha Atlantic Forest remnant, near the municipality of Maceió, Alagoas state, north-eastern Brazil. Lizards were collected by 
hand inside the bromeliads Aechmea Ruiz \& Pavón, 1794 and Hohenbergia Schult 1830 (Bromeliaceae: Bromelioideae) for 2-4 days weekly, from July 2004 to December 2005. Bromeliads were located on the ground, in trees and on granitic outcrops, at the edge of and inside the forest. After capture, lizards were euthanized with a lethal injection of lidocaine, fixed with $10 \%$ formalin and preserved in $70 \%$ ethanol. Voucher specimens were deposited in the Seção Herpetologia do Setor de Zoologia, do Museu de Historia Natural da Universidade Federal de Alagoas, under the acronym MUFAL. In the laboratory, lizards were necropsied and body cavity, lungs and the gastrointestinal tract were surveyed for endoparasites. Helminths found were counted, cleared in phenol, identified and deposited in the Coleção Helmintológica do Instituto de Biociências da Universidade Estadual Paulista Júlio de Mesquita Filho, Instituto de Biociências de Botucatu, São Paulo state, Brazil, under the acronym CHIBB (4756-4768).

Prevalence was calculated as (infected lizards/ examined lizards) $\times 100$, mean intensity of infection as arithmetic mean number of worms from infected lizards and mean abundance as total number of a particular parasite divided by total number of hosts (both infected and uninfected hosts), according to Bush et al. (1997). The discrepancy index $(D)$ was calculated as suggested by Poulin (1993). The index has a minimum value of zero $(D=0)$, when all hosts harbour the same number of parasites. When all parasites are found in a single host, aggregation is maximum $(D=1)$. This index was calculated with the software Quantitative Parasitology 3.0 (Rózsa et al., 2000).

The effect of host body size (SVL) on the intensity of infection was tested by a Pearson correlation. Differences in prevalence between the sexes were tested by Z-test for proportions. To test for differences in the intensity of infection between males and females, Mann-Whitney $U$-tests were performed. Throughout the text means are \pm 1 standard deviation.

\section{Results}

A single species of nematode was associated with B. lutzae: the Pharyngodonidae Spauligodon oxkutzcabiensis (Chitwood, 1938) Skrjabin, Schikhobalova and Lagodovskaja, 1960, with a total of 34 individuals recovered from the large intestine. Of the 57 lizards examined (38 adult females, 15 adult males and 4 juveniles), 13 were infected with $S$. oxkutzcabiensis (overall prevalence was $22.8 \%$ ). The mean intensity of infection was $2.62 \pm 1.19$. Discrepancy index $(D)$ was 0.813. Lizard SVL $(56.4 \pm 8.4 \mathrm{~mm}$, range $33.66-$ $68.83 \mathrm{~mm}$ ) had no effect on the intensity of infection ( $r=0.18, \quad P=0.19, \quad n=14)$. The prevalence of S. oxkutzcabiensis between males $(26.7 \%)$ and females $(26.3 \%)$ showed no significant difference $(Z=0.03$, $P=0.97)$. There was no significant difference between the mean intensity of infection between males $(3 \pm 1.4)$ and females $(2.2 \pm 1.31)$ (Mann-Whitney, $U=271.5, P=0.79)$.

\section{Discussion}

The occurrence of $S$. oxkutzcabiensis in B. lutzae represents a new host record. Spauligodon oxkutzcabiensis was previously reported from Peru and Paraguay in South America (Bursey \& Goldberg, 2004; Bursey et al., 2005). Thus, the present record represents a new country record, extending the actual distribution of S. oxkutzcabiensis to the Atlantic Forest of northeastern Brazil.

Nine species of lizard are known to harbour S. oxkutzcabiensis: Sceloporus malachiticus (Goldberg \& Bursey, 1992), S. formosus, S. grammicus, S. megalepidurus and S. mucronatus (Goldberg et al., 2003), Tropidurus guarani (Bursey \& Goldberg, 2004), Thecadactylus rapicauda (Chitwood, 1938), T. solimoensis (Bursey et al., 2005) and Phyllodactylus reissii (Goldberg \& Bursey, 2004). The species registered by Bursey et al. (2005) must actually be the recently described $T$. solimoensis, the distribution of which encompasses the locality of Cuzco Amazonico, Peru (see Bergmann \& Russell, 2007). Bogertia lutzae showed a low diversity and isolationist helminth fauna, and this may be the result of a simple enteric system, restricted vagility, ectothermy and a generalist diet (Goater et al., 1987; Aho, 1990). Moreover, the small size of $B$. lutzae may constrain the establishment of a richer parasite fauna, since many small lizard species have shown a depauperate helminth fauna; for example, Liolaemus lutzae (mean SVL $61.1 \mathrm{~mm}$ ) and Mabuya dorsivittata (mean SVL $64.9 \mathrm{~mm}$ ), which had two nematode species each (Rocha, 1995; Rocha et al., 2003). On the other hand, lizard species that attain higher SVL, such as Anolis punctatus (mean SVL $70.4 \mathrm{~mm}$ ) (Goldberg et al., 2006), harbour more endoparasites than small hosts, by facilitating niche differentiation and habitat segregation by competing species (Kuris et al., 1980). Host size and sex have a deep impact on diet and habitat preferences of lizards (Fitch, 1981), and this may also influence the patterns of prevalence and intensity of infection (Goater et al., 1987; Aho, 1990). Indeed, these correlations have been observed in a wide variety of Brazilian lizard species (Vrcibradic et al., 2000; Fontes et al., 2003; Anjos et al., 2005; Sousa et al., 2007). The lack of these correlations in B. lutzae may be due to our small sample size or host ecology, since differences of infection with age and sex are frequently linked with diet and habitat segregation (Van Sluys et al., 1994; Ribas et al., 1995, Anjos et al., 2005).

Spauligodon oxkutzcabiensis showed a highly aggregated pattern of distribution in B. lutzae. Poulin (1993) stated that this pattern is one of the most common features of metazoan parasite infections. In fact, further studies on basic ecological data of $B$. lutzae, such as diet and habitat use, are necessary to understand the hostparasite relationships, especially the absence of a relationship between patterns of parasitic infection and host size and sex.

\section{Acknowledgements}

We thank the Instituto Brasileiro do Meio Ambiente e dos Recursos Naturais Renováveis (IBAMA) for a collection permit (Process 02010.003061/05-58). 
This study was partially supported by grants from Fundação de Amparo à Pesquisa de Alagoas (FAPEAL; process 2004 0930160-1) and Fundação de Amparo à Pesquisa do Estado de São Paulo (FAPESP; processes 06/59 692-5 and 08/50 417-7). R.W.A. thanks Coordenação de Aperfeiçoamento de Pessoal de Nível Superior (CAPES) for a grant and E.M.X.F. thanks Conselho Nacional de Desenvolvimento Científico e Tecnológico (Bolsa produtividade Processo no. 304077/2008-9).

\section{References}

Aho, J.M. (1990) Helminth communities of amphibians and reptiles: comparative approaches to understanding patterns and processes. pp. 157-195 in Esch, G.W., Busch, A.O. \& Aho, J.M. (Eds) Parasite communities: patterns and processes. New York, Chapman \& Hall.

Anjos, L.A., Rocha, C.F.D., Vrcibradic, D. \& Vicente, J.J. (2005) Helminths of exotic lizard Hemidactylus mabouia from a rock outcrop area in southeastern Brazil. Journal of Helminthology 79, 307-313.

Bergmann, P.J. \& Russell, A.P. (2007) Systematics and biogeography of the widespread Neotropical gekkonid genus Thecadactylus (Squamata), with the description of a new cryptic species. Zoological Journal of the Linnean Society 149, 339-370.

Bursey, C.R. \& Goldberg, S.R. (2004) Helminths of Tropidurus guarani (Sauria: Tropiduridae) from Paraguay. Comparative Parasitology 71, 203-207.

Bursey, C.R., Goldberg, S.R. \& Parmelee, J.R. (2005) Gastrointestinal helminths from 13 species of lizards from Reserva Cuzco Amazónico, Peru. Comparative Parasitology 72, 50-68.

Bush, A.O., Lafferty, K.D., Lotz, J.M. \& Shostak, A.W. (1997) Parasitology meets ecology in its own terms: Margolis et al. revisited. Journal of Parasitology 83, 575-583.

Carvalho, C.M., Vilar, J.C. \& Oliveira, F.F. (2005) Répteis e Anfíbios. pp. 39-61 in Carvalho, C.M. \& Vilar, J.C. (Eds) Parque Nacional Serra de Itabaiana - Levantamento da Biota. Aracaju, Universidade Federal de Sergipe.

Chitwood, B.G. (1938) Some nematodes from the caves of Yucatan. Publication of the Carnegie Institute of Washington 491, 51-66.

Durette-Desset, M.C., Anjos, L.A. \& Vrcibradic, D. (2006) Three new species of the genus Oswaldocruzia Travassos, 1917 (Nematoda, Trichostrongylina, Molineoidea) parasites of Enyalius spp. (Iguanidae) from Brazil. Parasite 13, 115-125.

Fitch, H.S. (1981) Sexual size differences in reptiles. Miscellaneous Publication of the Museum of Natural History of University of Kansas 70, 1-72.

Fontes, A.F., Vicente, J.J., Kiefer, M.C. \& Van Sluys, M. (2003) Parasitism by helminths in Eurolophosaurus nanuzae (Lacertilia: Tropiduridae) in an area of rocky outcrops in Minas Gerais state, southeastern Brazil. Journal of Herpetology 37, 736-741.

Goater, T.M., Esch, G.W. \& Bush, A.O. (1987) Helminth parasites of sympatric salamanders: ecological concepts at infracommunity, component and compound community levels. American Midland Naturalist 118, 289-300.
Goldberg, S.R. \& Bursey, C.R. (1992) Gastrointestinal helminths of the lizard, Sceloporus malachiticus (Sauria: Iguanidae) from Coast Rica. Journal of the Helminthological Society of Washington 59, 125-126.

Goldberg, S.R. \& Bursey, C.R. (2004) Phyllodactylus reissii (Endoparasites). Herpetological Review 35, 395.

Goldberg, S.R., Bursey, C.R. \& Camarillo-Rangel, J.L. (2003) Gastrointestinal helminths of seven species of sceloporine lizards from Mexico. Southwestern Naturalist 48, 208-217.

Goldberg, S.R., Bursey, C.R. \& Vitt, L.J. (2006) Parasites of two lizard species, Anolis punctatus and Anolis transversalis (Squamata: Polychrotidae) from Brazil and Ecuador. Amphibia-Reptilia 27, 575-579.

Kuris, A.M., Blaustein, A.R. \& Alio, J.J. (1980) Hosts as islands. The American Naturalist 116, 570-586.

Poulin, R. (1993) The disparity between observed and uniform distributions: a new look at parasite aggregation. International Journal Parasitology 23, 937-944.

Ribas, S.C., Rocha, C.F.D., Teixeira-Filho, P.F. \& Vicente, J.J. (1995) Helminths (Nematoda) of the lizard Cnemidophorus ocellifer (Sauria: Teiidae): assessing the effect of rainfall, body size and sex in the nematode infection rates. Ciência e Cultura 47, 88-91.

Rocha, C.F.D. (1995) Nematode parasites of the Brazilian sand lizard, Liolaemus lutzae. Amphibia-Reptilia 16, 412-415.

Rocha, C.F.D., Vrcibradic, D., Vicente, J.J. \& CunhaBarros, M. (2003) Helminths infecting Mabuya dorsivittata (Lacertilia, Scincidae) from a high altitude habitat in Itatiaia National Park, Rio de Janeiro state, Southeastern Brazil. Brazilian Journal of Biology 63, 129-132.

Rózsa, L., Reiczigel, J. \& Majoros, G. (2000) Quantifying parasites in samples of hosts. Journal of Parasitology 86, $228-232$.

Sousa, B.M., Lima, S.S. \& Oliveira, A. (2007) Gastrointestinal helminth fauna of Enyalius perditus (Reptilia: Leiosauridae): relation to host age and sex. Journal of Parasitology 93, 211-213.

Van Sluys, M., Rocha, C.F.D. \& Ribas, S.C. (1994) Nematodes infecting the lizard Tropidurus itambere in southeastern Brazil. Amphibia-Reptilia 15, 405-408.

Van Sluys, M., Rocha, C.F.D., Bergallo, H.G., Vrcibradic, D. \& Ribas, S.C. (1997) Nematode infection in three sympatric lizards in an isolated fragment of restinga habitat in southeastern Brazil. Amphibia-Reptilia 18, 442-446.

Vicente, J.J., Van Sluys, M., Fontes, A.F. \& Kiefer, M.C. (2000) Subulura lacertilia sp.n. (Nematoda, Subuluridae) parasitizing the Brazilian lizard Tropidurus nanuzae Rodrigues (Lacertilia, Tropiduridae). Revista Brasileira de Zoologia 17, 1065-1068.

Vrcibradic, D., Cunha-Barros, M., Vicente, J.J., Galdino, C.A.C., Hatano, F.H., Van Sluys, M. \& Rocha, C.F.D. (2000) Nematode infection patterns in four sympatric lizards from a resting habitat (Jurubatiba) in Rio de Janeiro state, southeastern Brazil. Amphibia-Reptilia 21, 307-316.

Vrcibradic, D., Vicente, J.J. \& Bursey, C.R. (2007) Helminths infecting the lizard Enyalius bilineatus (Iguanidae, Leiosaurinae), from an Atlantic Rainforest area in Espirito Santo state, southeastern Brazil. Amphibia-Reptilia 28, 166-169. 